\title{
DINAMIKA KEPERCAYAAN RELASIONAL PADA KONSUMEN BISNIS E-COMMERCE DI INDONESIA
}

\author{
Jony Eko Yulianto, Theda Renanita \\ Fakultas Psikologi Universitas Ciputra Surabaya \\ Citraland CBD Boulevard, Surabaya, 60219 \\ jony.eko@ciputra.ac.id
}

\begin{abstract}
Despite the growing number of research on the topic of trust in e-commerce business in the field of psychology, most of these works are overly studied under the approach of personal trust that emphasizes individual-based intrapersonal psychological processes. This kind of approach offers useful insights yet remain to be an open discussion, particularly on its ability to explain social relations-based behaviors among Asian societies. The present study aimed to propose the relational trust approach that is arguably more relevant ontologically to Asian people. By involving nine participants in a Focus Group Discussion and eight participants in a series of semi-structured interview and performing thematic analysis to the empirical materials generated, the results revealed that psychological dynamics of relational trust is consisted of two main thematic clusters. Firstly, relational-trust forming phase, which is consisted of reference-based favorability, relational risk mitigation, and relational exclusivity; and relational-trust establishment phase, which is consisted relational confirmation of satisfactory and negligible mistakes. Theoretical implication and recommendations are discussed.
\end{abstract}

Keywords: e-commerce business; relational trust; social relationships; thematic analysis; qualitative study

\begin{abstract}
Abstrak
Penelitian-penelitian tentang kepercayaan dalam bisnis e-commerce telah banyak dilakukan dalam bidang ilmu psikologi. Namun demikian, mayoritas penelitian ini menggunakan pendekatan kepercayaan personal yang menekankan tentang dinamika psikologis intrapersonal individu. Penggunaan penelitian ini meskipun menawarkan kontribusi keilmuan yang penting, namun masih memiliki kelemahan-kelemahan khususnya adanya keterbatasan dalam menjelaskan fenomena perilaku masyarakat Asia yang kental dengan relasi sosial. Penelitian ini menawarkan pendekatan kepercayaan relasional yang secara ontologis lebih memiliki relevansi dengan karakteristik masyarakat Asia. Penelitian ini melibatkan sembilan orang dalam sesi diskusi kelompok terfokus yang dilanjutkan dengan wawancara mendalam pada delapan orang partisipan. Setelah melakukan analisis tematik pada transkripsi wawancara, hasil penelitian ini menunjukkan bahwa dinamika psikologis kepercayaan relasional terbagi menjadi dua kelompok besar. Pertama, fase pembentukan kepercayaan relasional, yang terdiri dari tema favorabilitas berbasis referensi, mitigasi risiko relasional, dan eksklusivitas relasional. Kedua, fase penegasan kepercayaan relasional, yang terdiri dari tema konfirmasi kepuasan relasional dan permakluman kesalahan. Implikasi teoritis dan rekomendasi dari penelitian ini dibahas pada bagian diskusi.
\end{abstract}

Kata kunci: analisis tematik; bisnis e-commerce; kepercayaan relasional; relasi sosial; studi kualitatif

\section{PENDAHULUAN}

Kajian mengenai peranan kepercayaan pada sebuah bisnis e-commerce telah secara ekstensif dilakukan oleh banyak ilmuwan dari berbagai bidang ilmu (cf. Hashima \& Fadhilb, 2017). Secara umum, para peneliti sepakat bahwa kepercayaan memiliki peranan penting yang mempengaruhi sikap konsumen, persepsi konsumen terhadap risiko, maupun keputusan konsumen untuk membeli (Agag \& El-Masry, 2016). Penelitian-penelitian terkini juga menegaskan peranan kepercayaan konsumen dalam menentukan efektivitas strategi pemasaran produk (Gregori, Daniele, \& Altinay, 2014), intensi konsumen dalam mengeksplorasi situs (Jai, Burns, \& King, 2013), serta persepsi konsumen terhadap keamanan situs maupun metode pembayaran (Yang dkk., 2015). Penelitian-penelitian tersebut menjadi bukti empiris yang 
menunjukkan bahwa kepercayaan merupakan aspek psikologis penting yang perlu mendapatkan perhatian serius dalam operasionalisasi bisnis e-commerce.

Prospek bisnis e-commerce tampaknya juga semakin cerah, bukan hanya di negara maju, tetapi juga di negara berkembang. Di Indonesia, prevalensi pengguna internet diprediksikan akan meningkat dan mencapai 200 juta pengguna internet aktif pada tahun 2030 (Singapore Post e-Commerce, 2014). Pada tahun 2015, total transaksi e-commerce di Indonesia dilaporkan mencapai 2.539 juta dolar (Redwing Asia, 2014). Hal ini menunjukkan bahwa kajian mengenai kepercayaan terhadap bisnis e-commerce masih relevan dan penting untuk dilakukan. Pemahaman mengenai mekanisme kepercayaan konsumen terhadap bisnis $e$ commerce akan membantu negara-negara berkembang menerapkan strategi internasionalisasi (Guercini \& Runfola, 2015), mempromosikan dan menegaskan posisi budaya nasional pada tataran global, meningkatan kapasitas ekonomi serta memperoleh keuntungan-keuntungan lainnya (Jahanshahi, Zhang, \& Brem, 2013).

Meskipun signifikansi peranan kepercayaan dalam bisnis e-commerce telah diakui, namun seperti apa konstruksi kepercayaan dalam kaitannya dengan proses pengambilan keputusan konsumen untuk membeli produk atau jasa tampak masih belum konklusif. Mayoritas penelitian dalam bidang psikologi menggunakan pendekatan yang mempercayai bahwa kepercayaan adalah konstruk psikologis yang bersifat personal, yang selanjutnya dalam penelitian ini akan disebut dengan istilah kepercayaan personal. Kepercayaan personal digambarkan berakar dari aspek intra-individual sebagai determinan langsung terjadinya transaksi ekonomi. Contoh dari pendapat ini misalnya dapat kita lihat dari riset Amaro dan Duarte (2015) yang melakukan pengujian model integratif berbasis the Theory of Reasoned Action, the Theory of Planned Behaviour, the Technology Acceptance Model dan the
Innovation Diffusions Theory. Mereka menemukan bahwa sikap, kompatibilitas, dan persepsi terhadap risiko pada bisnis $e$ commerce sebagai determinan perilaku pembelian. Penelitian lain yang dilakukan oleh Chiu dkk. (2014) menemukan bahwa faktor yang mempengaruhi konsumen dalam melakukan pembelian adalah tata nilai utilitarian (utilitarian value), tata nilai hedonis (hedonic value), dan persepsi terhadap risiko (perceived risk).

Peranan kepercayaan personal sebagai variabel mediator dalam proses transaksi ekonomi ini terus dikembangkan dalam penelitian-penelitian lainnya. Dalam kajian yang lebih mutakhir, Amaro dan Duarte (2016) kemudian mengintegrasikan kepercayaan personal dengan elemen-elemen yang terdapat pada the Theory of Planned Behaviour untuk mengeksplorasi determinan transaksi ekonomi pada bisnis e-commerce dan menemukan bahwa sikap terhadap vendor, persepsi terhadap risiko, dan persepsi terhadap kontrol perilaku (perceived behavioural control) memiliki pengaruh langsung terhadap transaksi pembelian. Kepercayaan personal konsumen dan pengaruh sosial ditemukan tidak memiliki dukungan langsung terhadap transaksi pembelian pada bisnis e-commerce. Dengan kata lain, hanya karena seorang konsumen mempercayai sebuah produk pada $e$ commerce, belum tentu ia akan melakukan transaksi ekonomi untuk membeli. Riset juga menunjukkan bahwa masyarakat Asia cenderung memandang e-commerce sebagai basis data referensi harga. Artinya, untuk jenis-jenis barang tertentu dengan harga yang relatif mahal seperti barang elekronik, pembeli memilih tetap melakukan pembelian secara langsung ke toko (Garbarino \& Maxwell, 2010).

Perkembangan penelitian terkini tentang kepercayaan personal juga telah masuk ke tahapan sekuensial kemunculan kepercayaan. Tidak seperti mayoritas literatur yang berpendapat bahwa kepercayaan merupakan entitas yang harus muncul sebelum transaksi 
ekonomi (lihat Garbarino \& Maxwell, 2010), tetapi peneliti juga menemukan sebaliknya: kepercayaan dalam konteks bisnis $e$ commerce juga dapat muncul setelah transaksi terjadi. Kim, Chung, dan Lee (2011) misalnya, melihat kepercayaan sebagai mediator yang menghubungkan kepuasan dan loyalitas konsumen pada bisnis e-commerce. Dalam konteks ini, kepercayaan merupakan entitas yang muncul setelah transaksi ekonomi dilakukan, sehingga memungkinkan konsumen untuk melakukan pembelan berulang. Dalam penelitian lainnya, Wang dkk. (2015) menemukan kepercayaan sebagai mediator kualitas hotel dan intensi untuk melakukan pemesanan secara online, artinya kepercayaan muncul sebagai efek dari sikap terhadap kualitas vendor. Hal ini dapat dipahami mengingat konsumen pada bisnis konsumen mengembangkan skema kognitif untuk mempercayai sesuatu yang tidak nampak (intangible) (Beldad, de Jong, \& Steehouder, 2010).

Kajian-kajian mengenai kepercayaan yang dipaparkan di atas cenderung memandang kepercayaan sebagai kepercayaan personal. Kepercayaan personal muncul sebagai respon individu karena menemukan objek yang dapat dipercaya (trustworthy). Maka, kepercayaan personal muncul sebagai hasil dari pemaknaan dan keputusan individual yang diberikan oleh pemberi kepercayaan (trustor) dan penerima kepercayaan (trustee). Kepercayaan muncul sebagai stase psikologis yang membuat seorang individu bersedia untuk menerima atau mengambil risiko berdasarkan estimasi dan intensi positif terhadap objek. Singkatnya, konsep tentang kepercayaan personal muncul dengan menekankan peran aktif dinamika psikologis individual dalam membentuk rasa percaya pemberi kepercayaan kepada penerima kepercayaan dan menempatkan faktor-faktor lainnya dalam posisi sekunder.

Permasalahannya, cara memandang kepercayaan sebagai kepercayaan personal memiliki keterbatasan-keterbatasan.
Pertama, kepercayaan personal terfokus pada individu pemberi kepercayaan (trustor). Dalam konteks e-commerce, pembelian tidak hanya semata-mata ditentukan oleh konsumen. Beberapa kajian menemukan adanya fenomena dimana individu tetap berani melakukan transaksi pembayaran meskipun belum pernah memiliki pengalaman transaksi sebelumnya (Sharma, Bharadhwaj, \& Marshall, 2010). Studi lainnya menemukan adanya fenomena di mana vendor tidak memiliki cukup kriteria untuk dapat dipercaya, misalnya vendor yang memiliki sedikit pengikut (follower), atau kualitas gambar produk yang tidak meyakinkan, tetapi konsumen tetap berani melakukan pembelian karena ketersediaan barang (Lee, Park, \& Han, 2007). Fenomenafenomena ini menunjukkan bahwa kepercayaan personal yang selama ini dijadikan rujukan dalam menjelaskan fenomena kepercayaan tidak cukup mampu menjelaskan fenomena transaksi ekonomi pada bisnis e-commerce.

Keterbatasan kedua dari pandangan kepercayaan personal adalah pengabaian elemen-elemen di luar pemberi kepercayaan (trustor) dan penerima kepercayaan (trustee). Fenomena-fenomena mengenai pembelian $e$ commerce seringkali melibatkan aspek testimonial dan rekomendasi dari relasi. Testimonial pembelian produk dan rekomendasi dari orang lain menunjukkan bahwa penggunaan kepercayaan personal dalam menjelaskan fenomena transaksi ekonomi pada bisnis e-commerce telah melupakan sebuah hal yang penting, yakni konteks. Konteks merupakan elemen eksternal yang turut mempengaruhi munculnya kepercayaan dan mempengaruhi pengambilan keputusan konsumen dalam melakukan transaksi pembelian. Konteks dapat berupa agama, budaya, norma-norma kelompok yang mempengaruhi individu dalam mengambil sikap atau perilaku, maupun relasi sosial yang dimiliki oleh konsumen. 
Secara paradigmatik, signifikansi relasi dalam kompleksitas perilaku individu juga didukung oleh temuan-temuan yang menyatakan bahwa kepercayaan pada individu, khususnya pada masyarakat Asia, telah bergeser fokusnya dari psikologi individual menjadi psikologi yang berorientasi pada relasi sosial (Ho \& Chau, 2009; Hwang, 2012). Orientasi relasional pada prinsipnya berargumen bahwa kepercayaan bukan saja produk dialektis internal dari dua pihak, tetapi produk relasional dan metarelasional yang melibatkan banyak elemen. Berbagai paparan hasil penelitian empiris di atas menunjukkan bahwa diperlukan sebuah konsep alternatif untuk menjawab keterbatasan kepercayaan personal dalam menjelaskan fenomena transaksi jual beli pada bisnis e-commerce.

Berdasarkan deskripsi di atas, peneliti memandang perlu untuk mengajukan sebuah alternatif dalam memandang kepercayaan. Pada penelitian ini, peneliti mengajukan konsep kepercayaan relasional, yakni cara pandang kepercayaan sebagai sebuah entitas yang terhubung dengan relasi sosial. Kepercayaan relasional pada konteks ini kami tawarkan sebagai respon dari keterbatasan kepercayaan personal (truster to trustee) yang secara empiris belum mampu secara tegas menjelaskan fenomena transaksi ekonomi pada konsumen bisnis e-commerce (lihat Amaro \& Duarte, 2016). Kepercayaan relasional memperhitungkan peranan relasi sosial, baik pada konsumen (truster) maupun vendor bisnis e-commerce (trustee) dalam melakukan pembentukan sikap, pengambilan keputusan membeli, maupun evaluasi. Relasi yang dimaksud di sini berbeda dengan yang diajukan oleh Paswan dkk. (2011) yang lebih memandang kepercayaan relasional sebagai orientasi vendor untuk membentuk relasi jangka panjang konsumen sehingga transaksi jual beli tidak hanya dipandang dalam unit satuan transaksi, tetapi lebih kepada satuan relasi. Sedangkan pada penelitian ini, kepercayaan relasional merupakan integrasi kepercayaan dan relasi sosial yang dimiliki baik oleh konsumen maupun vendor dalam membentuk perilaku ekonomi.

Kepercayaan relasional ini relevan dan penting untuk dieksplorasi mengingat kajiankajian mengenai kepercayaan juga meluas seiring dengan munculnya temuan-temuan baru yang menunjukkan bahwa kepercayaan muncul sebagai produk sosial yang berkaitan erat dengan jejaring sosial, identitas sosial, serta kerabat dan teman dekat. Artinya, kepercayaan bukan saja muncul dari sebagai hasil sebuah proses dinamika intrapersonal, tetapi juga hasil interaksi sosial antarindividu. Meskipun beberapa kajian tentang kepercayaan telah menunjukkan hasil penelitian yang bermuara pada interaksi sosial individu, namun sejauh penelusuran peneliti, belum ada studi empiris yang secara komprehensif mampu menjelaskan dinamika psikologis kepercayaan relasional, khususnya dalam konteks bisnis e-commerce dengan menggunakan Asia sebagai konteks penelitian.

Secara ontologis, kepercayaan relasional berakar dari filsafat Relasionalisme Konfucian (Confucian Relationalism) yang mempercayai bahwa setiap manusia bukanlah sebuah entitas tunggal, tetapi entitas relasional, yakni individu yang terhubung dengan manusia yang lain (Hwang, 2012). Implikasinya, relasi interpersonal dalam perspektif relasionalisme tidak hanya memandang individu dalam sisi historisitas individualnya saja, tetapi bagaimana pembentukan makna yang ia alami berdasarkan interaksi dengan lingkungannya. Paradigma ini banyak digunakan oleh berbagai bidang ilmu sosial. Dalam psikologi, paradigma ini diperkenalkan oleh Ho (1993) melalui konsep orientasi relasional (relational orientation) dan diri relasional (relationalself). Dalam bidang ilmu politik, Wilson (1974) juga memperkenalkannya sebagai orientasi relasional (relational orientation). Dalam bidang ilmu sosiologi, Lebra (1976) menyebutnya sebagai relativisme sosial (social relativism), sedangkan di sosiologi, 
Hsu (1971) memperkenalkan terma homeostasis psikososial (psychosocial homeostasis). Berbagai telaah interdisipliner mengenai relasionalisme di atas menunjukkan bahwa kepercayaan relasional memiliki akar keilmuan dan fakta empiris pendukung yang memadai untuk dijadikan sebagai tesis dalam memandang kepercayaan konsumen dalam bisnis $e$-commerce.

Eksplorasi kepercayaan relasional dalam konteks e-commerce ini melengkapi berbagai fokus penelitian kepercayaan pada bisnis $e$ commerce sebelumnya. Matt dan Heiss (2016) telah meneliti kepercayaan terhadap vendor yang terlibat dalam bisnis $e$ commerce. Selain itu, terdapat pula penelitian mengenai kepercayaan terhadap supplier bisnis e-commerce yang ditinjau dari pemilihan nama brand (Otim \& Grover, 2010). Saat ini, perkembangan penelitian mengenai kepercayaan dalam bisnis $e$ commerce terkini bahkan tidak hanya berfokus pada aspek manusia dan infrastruktur teknologi informasi semata (Akter \& Wamba, 2016; Faily, Power, \& Flechais, 2016), tetapi integrasi dari keduanya. Hal ini menunjukkan bahwa posisi fokus penelitian ini terletak pada paradigma dalam memandang kepercayaan sebagai aspek penting dalam bisnis $e$ commerce. Kajian yang menggunakan kepercayaan dalam kerangka filosofi relasionalisme dengan pendekatan kualitatif pada konteks e-commerce sejauh ini belum pernah dilakukan sebelumnya. Maka, dalam penelitian ini peneliti mengajukan pertanyaan penelitian, "Bagaimana dinamika kepercayaan relasional pada konsumen bisnis e-commerce di Indonesia?"

\section{METODE}

Pendekatan. Fokus penelitian ini adalah dinamika kepercayaan relasional. Eksplorasi dinamika psikologis membutuhkan investigasi yang intensif dan karenanya, pendekatan yang paling sesuai untuk penelitian ini adalah pendekatan kualitatif. Penelitian kualitatif memungkinkan peneliti untuk menggali informasi secara mendalam mengenai dinamika kepercayaan relasional konsumen e-commerce terhadap vendor. Karakteristik relasi yang melibatkan pemaknaan individu juga menjadi alasan lain mengapa pendekatan kualitatif menjadi pendekatan paling sesuai untuk penelitian ini. Dalam penelitian ini, peneliti berupaya melakukan analisis tematik pada tema-tema yang menonjol pada hasil interview. Filsafat relasionalisme yang menjadi landasan ontologis dalam penelitian ini memiliki implikasi metodologis, yakni unit analisis bukan lagi terletak pada individu atau situasi, tetapi relasi antar dua pihak (Ho \& Chau, 2009). Hwang (2012) menyebut hal ini sebagai relasi dialektikal, dimana fenomena sosial dibagi menjadi sistem sosial hierarkis, seperti intra-individual, interpersonal, kelompok, dan antar-kelompok. Pembagian ke dalam domain-domain tersebut memungkinkan peneliti memahami interrelasi dari aspek-aspek tersebut, baik dalam aspek parsial maupun aspek global (partwhole relation). Penelitian ini akan menitikberatkan pada aspek interpersonal sebagai fokus bahasan dan menempatkan level lainnya sebagai latar belakang.

\section{Pelaksanaan Pengambilan Data Penelitian.}

Penelitian ini terdiri dari dua fase, yakni diskusi kelompok terfokus dan wawancara mendalam. Diskusi kelompok terfokus dilaksanakan selama kurang lebih 2 jam di ruang FGD Fakultas Psikologi Universitas Ciputra Surabaya dan diikuti oleh sembilan partisipan. FGD dipimpin langsung oleh kedua peneliti pada bulan April 2016. Wawancara mendalam dilaksanakan setelah formulasi hasil FGD selesai, sehingga peneliti dapat menyusun pertanyaan pemandu yang lebih sesuai dengan kondisi di lapangan. Subjek-subjek yang dipilih untuk mengikuti wawancara mendalam merupakan orang-orang memenuhi kriteria pemilihan responden. Wawancara dilaksanakan secara individual dengan masing-masing subjek dengan durasi wawancara minimal selama 1 jam. Periode pelaksanaan wawancara 
dilakukan pada rentang bulan April hingga Agustus 2016 di Laboratorium Observasi dan Wawancara Fakultas Psikologi Universitas Ciputra Surabaya dan diikuti oleh total 9 orang partisipan. Setiap percakapan direkam dengan menggunakan Sony Profesional Voice Recorder tipe ICDAX412F. Setiap partisipan menandatangani lembar persediaan menjadi partisipan penelitian setelah peneliti menerangkan hak dan kewajiban penelitian dalam penelitian ini. Durasi pelaksanaan wawancara mendalam tiap responden rata-rata adalah $1.5 \mathrm{jam}$.

Partisipan Penelitian. Dalam menentukan partisipan penelitian, peneliti memberikan beberapa kriteria: (1). Memiliki frekuensi melakukan transaksi e-commerce selama 3 kali per bulan; (2). Memiliki minimal biaya transaksi sebesar Rp 200.000 per bulan; (3). Bersedia mengikuti rangkaian penelitian sampai akhir. Dengan memenuhi ketiga kriteria di atas, diasumsikan setiap partisipan merupakan konsumen aktif e-commerce. Terdapat total 9 partisipan yang mengikuti diskusi kelompok terfokus, dan 8 orang yang mengikuti sesi wawancara mendalam. Tujuh dari total sembilan (63\%) responden beretnis Tionghoa. Berikut ini disajikan tabel rekapitulasi profil partisipan penelitian ini:

Tabel 1.

Partisipan Penelitian

\begin{tabular}{|c|c|c|c|c|c|}
\hline Nama & Status & Usia & $\begin{array}{c}\text { Frekuensi } \\
\text { transaksi per } \\
\text { bulan }\end{array}$ & $\begin{array}{l}\text { Nilai transaksi } \\
\text { per bulan }\end{array}$ & Pengambilan data \\
\hline Anne & $\begin{array}{l}\text { Konsumen } \\
\text { Pemilik } \\
\text { Usaha }\end{array}$ & 19 & 3 & Rp 500.000 & $\begin{array}{c}\text { Focus Group Discussion } \\
\text { In-depth Interview }\end{array}$ \\
\hline Betty & Konsumen & 22 & 4 & Rp 650.000 & $\begin{array}{l}\text { Focus Group Discussion } \\
\text { In-depth Interview }\end{array}$ \\
\hline Clara & Konsumen & 23 & 3 & Rp1.200.000 & $\begin{array}{l}\text { Focus Group Discussion } \\
\text { In-depth interview }\end{array}$ \\
\hline Debbie & Konsumen & 24 & 5 & Rp 1.500 .000 & $\begin{array}{l}\text { Focus Group Discussion } \\
\text { In-depth Interview }\end{array}$ \\
\hline Elena & $\begin{array}{l}\text { Konsumen } \\
\text { Pemilik } \\
\text { Usaha }\end{array}$ & 24 & 3 & Rp 2.000.000 & $\begin{array}{l}\text { Focus Group Discussion } \\
\text { In-depth Interview }\end{array}$ \\
\hline Florence & Konsumen & 22 & 4 & Rp 500.000 & Focus Group Discussion \\
\hline Hanna & Konsumen & 28 & 3 & Rp 300.000 & In-depth Interview \\
\hline Sylvia & $\begin{array}{l}\text { Konsumen } \\
\text { Pemilik } \\
\text { Usaha }\end{array}$ & 20 & 6 & Rp 400.000 & $\begin{array}{l}\text { Focus Group Discussion } \\
\text { In-depth Interview }\end{array}$ \\
\hline Amelia & Konsumen & 22 & 4 & Rp 500.000 & $\begin{array}{c}\text { Focus Group Discussion } \\
\text { In-depth Interview }\end{array}$ \\
\hline
\end{tabular}

Analisis dan Interpretasi Data. Analisis dan interpretasi data pada penelitian ini didasarkan dari analisis tematik. Secara definitif, analisis tematik merupakan kumpulan informasi yang memuat daftar tema, model tema, indikator yang kompleks, dan klasifikasi-klasifikasi tema yang sejenis (Braun \& Clarke, 2006). Melalui penggolongan informasi ke dalam berbagai tema yang didapatkan melalui pembacaan transkripsi, peneliti diharapkan mampu melihat pola-pola pembentukan makna melampaui data. Pola-pola inilah yang nantinya akan dijadikan sebagai landasan dalam pengambilan kesimpulan (Braun \& Clarke, 2006).

Tema-tema yang muncul sebagai sub-judul temuan dalam penelitian ini didasarkan pada hasil coding saat melakukan analisis tematik. 
Peneliti menciptakan nama-nama kategori dan menempatkannya sebagai temuan dari transkrip wawancara. Praktik ini dalam penelitian kualitatif tergolong sebagai datadriven analysis (Nowell dkk., 2017). Dengan berorientasi kepada data, peneliti berupaya untuk tidak terjebak pada praktik verifikasi teori (theory driven) tentang kepercayaan personal sebagai konsep yang telah ada, tetapi lebih bertujuan untuk melakukan eksplorasi terhadap fenomena sosial yang dialami oleh partisipan. Tema-tema ini kemudian diteorisasikan dengan literatur mutakhir dan konsep yang relevan sebagai pembanding untuk melihat dinamika kepercayaan relasional.

Dalam proses pengkodingan hasil analisis tematik, kedua peneliti dibantu oleh seorang asisten peneliti yang memastikan bahwa proses koding telah dilakukan dengan cermat dan valid. Asisten peneliti memiliki kualifikasi sebagai seorang mahasiswa psikologi yang telah lulus mata kuliah Metode Penelitian Kualitatif. Setiap perbedaan-perbedaan pendapat didiskusikan dalam beberapa sesi diskusi sehingga interpretasi yang disajikan dalam artikel ini telah disetujui oleh keseluruhan tim penelitian.

\section{HASIL DAN PEMBAHASAN}

Hasil penelitian ini dibagi menjadi dua bagian, yakni fase pembentukan kepercayaan relasional dan fase penegasan kepercayaan relasional. Fase pembentukan merupakan fase yang terjadi sebelum transaksi pembelian dilakukan, sedangkan fase penegasan terjadi setelah transaksi pembelian dilakukan. Transaksi ekonomi merupakan acuan yang digunakan sebagai separasi kedua bagian tersebut karena dua argumen berikut ini: Pertama, kepercayaan dalam konteks e-commerce sangat memungkinkan baru lahir setelah fase transaksi ekonomi dilakukan (Sharma, Bharadhwaj, \& Marshall, 2010). Separasi dengan menggunakan acuan transaksi ekonomi akan membantu mengakomodasi jenis konsumen yang memiliki impulsivitas tinggi dalam membeli.

Kedua, transaksi ekonomi merupakan penanda keperilakuan (behavioral sign) untuk menunjukkan menifestasi kepercayaan yang telah terbentuk. Hasil-hasil penelitian mengenai koherensi sikap dan perilaku menunjukkan bahwa bias implisit yang mengakibatkan tidak koherennya sikap dan perilaku juga dapat eksis dalam dunia konsumen (Siamagka \& Balabanis, 2015). Dengan menjadikan transaksi ekonomi sebagai acuan separasi, maka akan ada upaya konkret untuk mengakomodasi jenis konsumen yang kemungkinan memiliki sikap berbeda yang diakibatkan oleh sikap etnosentrisme, kosmopolitanisme, dan sebagainya (Zeugner-Roth \& Diamantopoulos, 2015)

\section{Fase Pembentukan Kepercayaan Relasional}

Fase pembentukan kepercayaan relasional dijabarkan melalui empat topik, yakni favorabilitas berbasis referensi, kongruensi dengan identitas sosial, eksklusivitas relasional, dan manajemen eror secara relasional. Empat topik ini merupakan topik yang saling terhubung satu sama lain, namun tidak berbentuk urutan. Masing-masing penjelasan dari topik tersebut adalah sebagai berikut:

\section{Favorabilitas Berbasis Referensi (Reference-based Favorability).} Pembentukan kepercayaan pada konsumen $e$ commerce salah satunya diawali dari munculnya preferensi. Preferensi di sini merujuk kepada afeksi positif terhadap barang atau jasa yang ditawarkan oleh vendor e-commerce. Pada umumnya, literatur-literatur kepercayaan lebih cenderung menyoroti peranan pengambilan keputusan subjek yang dipengaruhi oleh aspek-aspek psikologis pada individu seperti norma subjektif, kepercayaan, dan lain-lain (cf. McKnight \& Chervany, 2001). Namun preferensi pada konsumen e-commerce tampak cenderung berpijak pada referensi 
yang diberikan oleh pihak lainnya. Sumbersumber referensi yang meningkatkan favorabilitas diantaranya adalah: Testimoni dari pembeli lainnya, referensi dari relasi dekat, angka statistik atau indeks kepuasan konsumen pada sebuah barang atau jasa spesifik yang ditawarkan, atau referensi dari sumber lainnya. Ilustrasi dari topik ini dapat disimak melalui petikan wawancara berikut ini:

\begin{abstract}
"Saya percaya kepada sebuah vendor ecommerce di Instagram karena ia mempromosikan produknya melalui selebgram yang modis dan cantik. Dengan memperhatikannya, saya tahu persis bahwa barang tersebut bagus dan pas buat saya. Hampir tidak mungkin saya membeli sebuah barang jika tidak ada referensi dari selebgram". (Debbie, 24 tahun)
\end{abstract}

"Saya membelinya dari sebuah toko online yang saya tahu dari rekan saya di kantor. Toko online tersebut belum sebesar toko online yang biasa sering muncul di internet. Namun menurut rekan saya, pelayanannya bagus, sering memberikan bonus, dan selama ini hampir tidak pernah saya temukan komplain dari pelanggan. Selain itu, testimoni dari para pembeli sebelumnya juga bagus-bagus. Jadi tidak masalah bagi saya untuk mencobanya, meskipun followernya di Instagram masih sedikit”. (Anne, 20 tahun)

Pembentukan favorabilitas berbasis referensi merupakan fenomena relasi yang khas pada bisnis e-commerce. Penelitian-penelitian mengenai sumber pembentukan kepercayaan cenderung menekankan pentingnya persepsi keterpercayaan (trustworthiness) pada lawan dialog (Faturochman, 2011). Persepsi mengenai keterpercayaan ini cenderung besar pada orang-orang yang telah dikenal dan memiliki hubungan baik, dan secara analog rendah pada orang asing (stranger). Namun pada konteks e-commerce, persepsi mengenai keterpercayaan mengalami pergeseran-pergeseran.
Pertama, keterpercayaan terhadap vendor tidak semata-mata ditentukan oleh vendor itu sendiri, tetapi juga pihak ketiga. Pihak ketiga dalam hal ini menjadi sumber pertimbangan pengambilan keputusan dari konsumen. Kedua, referensi dari pihak ketiga memungkinkan konsumen tetap dapat membentuk kepercayaan meskipun subjek tidak memiliki pengalaman interaksi langsung bersama dengan vendor. Hal ini menunjukkan peran relasi sebagai asuransi kepercayaan (trust insurance) tetap dapat eksis sekalipun dalam jenis relasi ekonomis yang tidak melibatkan afeksi interpersonal antara pembeli dan vendor e-commerce.

Melalui contoh-contoh petikan wawancara di atas, para subjek penelitian memperlihatkan bahwa ketertarikan terhadap objek tidak semata-mata muncul secara independen antara subjek dan vendor, tetapi juga interaksi tiga pihak. Pembentukan favorabilitas berbasis referensi ini sangat kentara terjadi pada subjek-subjek jenis rational optimist dan rational pesimist. Referensi, baik dari website, testimoni, maupun sumber lain merupakan landasan untuk menentukan sikap dalam membeli. Analisis mengenai kualitas testimoni, statistik kepuasan konsumen, daftar keluhan konsumen, serta deskripsi pembelian lainnya akan dipertimbangkan dengan serius dan mempengaruhi pandangan terhadap kualitas vendor e-commerce. Sedangkan pada jenis subjek yang impulsif, baik tipe optimist maupun pesimist, proses pembentukan favorabilitas berbasis referensi juga terjadi namun jarak terbentuknya favorabilitas dan pengambilan keputusan transaksi berlangsung lebih cepat.

\section{Kongruensi Identitas Sosial (Social} Identity Congruency). Kesesuaian antara identitas sosial dan karakteristik vendor $e$ commerce juga merupakan salah satu faktor yang membentuk adanya kepercayaan relasional pada konsumen e-commerce. Identitas sosial adalah sebuah kesadaran dari seorang individu bahwa ia adalah anggota dari sebuah kelompok sosial yang lebih 
besar. Implikasinya, individu akan menunjukkan sikap dan perilaku yang cenderung sama dengan karakteristik identitas sosialnya. Dengan catatan, individu memiliki asosiasi yang kuat dengan identitas sosial yang ia miliki. Berdasarkan hasil wawancara dengan para subjek, salah satu identitas sosial yang paling kentara (salient sosial identity) adalah agama. Subjek akan cenderung untuk mempercayai vendor $e$ commerce yang menunjukkan atribut agama yang sama dengan agama yang ia anut. Ilustrasi penjelasan di atas dapat disimak melalui petikan wawancara berikut ini:

"Ya saya kan Muslim. Jadi saya lebih suka untuk membeli produk-produk tertentu yang ada nuansa Islamnya. Website online shop yang Islami lebih membuat saya nyaman dan aman. Saya merasa mereka tidak akan menipu. Lagipula semua benda yang saya cari mayoritas memang ada kaitannya dengan Islam. Misalnya hijab atau mukena". (Amel, 23 tahun)

"Aku suka belanja di online shop yang khusus menjual produk untuk Muslimah. Nggak bermaksud agamis ya, Pak. Tapi aku ngerasa kalau dia spesialisasi menjual barang-barang keagamaan, aku ngerasa dia lebih jujur gitu. Secara psikologis juga kayaknya lebih percaya karena kan memang diajarkan sesama umat Muslim harus saling menjaga." (Clara, 23 tahun)

Asosiasi yang mendalam terhadap identitas sosial memberikan alasan kepada subjek penelitian untuk mempercayai vendor yang menunjukkan atribut yang sama. Favorabilitas terhadap identitas sosial ini pula yang memberikan keyakinan kepada subjek untuk sampai pada kesimpulan bahwa vendor yang memiliki atribut identitas sosial akan cenderung dapat dipercaya. Dalam konteks ini, terdapat elemen proksimitas dan kongruensi yang menjadi pemicu munculnya favorabilitas. Sejauh mana vendor dapat menunjukkan asosiasi yang kuat terhadap sebuah identitas sosial tertentu, maka semakin tinggi pula peluang ia dapat dipercaya. Maka, vendor-vendor yang memiliki spesifikasi dalam produk akan cenderung lebih dipercayai karena lebih dapat membentuk persepsi keterandalan. Subjek yang memiliki asosiasi kuat terhadap Islam, akan cenderung berbelanja produkproduk agama kepada vendor yang secara khusus menjual barang-barang tersebut dibanding vendor serba ada. Internalisasi terhadap sebuah identitas sosial terjadi ketika individu secara kuat mengidentifikasikan dirinya sebagai bagian dari sebuah kelompok sosial tertentu dan mempengaruhi intensi melakukan perilaku spesifik, termasuk transaksi ekonomi. Hal ini menunjukkan peranan identitas sebagai pembentuk kepercayaan interpersonal yang bersifat relasional.

Secara tipologis, peranan identitas sosial sebagai determinan pembentuk kepercayaan relasional ini sangat kentara pada konsumen tipe rasionalis. Identitas sosial merupakan salah satu elemen sumber rasionalisasi sejauhmana vendor e-commerce dapat dipercaya (trustworthy). Optimisme dan pesimisme dalam keputusan untuk membeli dalam konteks ini sangat dipengaruhi oleh sejauhmana subjek memiliki pemaknaan mendalam terhadap identitas sosialnya. Kepercayaan terhadap keterandalan identitas sosial membuat subjek cenderung memiliki kepercayaan terhadap kualitas produk atau jasa yang ditawarkan. Pada tipe konsumen yang impulsif, dinamika ini cenderung berlangsung dengan lebih cepat. Artinya, pertimbangan mengenai sejauhmana produk atau jasa adalah berkualitas tidak membutuhkan waktu pertimbangan yang kompleks.

\section{Mitigasi Risiko Relasional (Relational Risk} Mitigation). Salah satu unsur mendasar dalam transaksi ekonomi dalam bisnis $e$ commerce adalah manajemen risiko. Sifat relasi interpersonal antara konsumen dan vendor merupakan relasi yang tidak melibatkan unsur afeksi sehingga satuan kepercayaan dihitung dalam satuan transaksi (Yulianto, 2016). Temuan struktural pada 
penelitian ini menunjukkan kecenderungan subjek dalam mengembangkan pola mitigasi risiko yang berlandaskan relasi. Sub-tema mengenai mitigasi risiko ini khas dalam diskursus tentang rencana pembelian karena menyadari bahwa dalam transaksi $e$ commerce, konsumen tidak dapat bertatap muka dengan vendor. Hal ini mengakibakan risiko menjadi menguat. Berdasarkan wawancara, pola mitigasi risiko yang dikembangkan oleh subjek menunjukkan tema-tema yang berkaitan dengan relasi sosial yang ia punya.

"Saya dekat dengan empat sahabat saya. Kami selalu bersama-sama ke kampus, menjadi satu kelompok untuk mengerjakan tugas bersama sejak semester satu hingga saat ini kami ada di semester 6. Selalu ada diantara kami yang membeli barang di sebuah online shop. Jika satu orang membeli, maka semua akan ikut membeli. Supaya kompak, supaya satu punya dan yang lain juga punya. Terkadang kami tidak memiliki alasan yang spesifik mengapa harus membeli. Hanya sebagai bukti bahwa kami loyal satu dengan yang lain. Meskipun onlineshopnya baru. ...pernah ditipu, tapi tidak apa-apa. Karena kami senang bersama, dan rugipun bersama." (Elena, 22 tahun).

\begin{abstract}
"Saya percaya karena teman-teman saya percaya. Mau nolak itu nggak enak, Pak. Saya ya merem aja lah waktu ikutan bayar. Eh, waktu barangnya datang ternyata jelek, tidak seperti di gambarnya. Marah sih. Tapi akhirnya ya kami tetap tertawa bersama karena semua mengalami hal yang sama. Lagipula dengan membeli bersama-sama, kami mendapatkan keuntungan karena menghemat biaya pengiriman. Kami sudah senang sekali saat bisa menghemat ongkos kirimnya". (Betty, 22 tahun)
\end{abstract}

Apa yang dialami oleh Betty memberikan insight menarik mengenai ketakutan untuk memiliki opini minoritas. Individu yang memiliki persepsi bahwa ia memiliki opini minoritas dalam kelompok akan cenderung tidak mengungkapkannya secara asertif. Ketakutan untuk memiliki opini pribadi ini terbagi menjadi dua dimensi, yakni ketakutan untuk diketahui bahwa individu memiliki opini minoritas, dan ketakutan untuk ditolak secara sosial. Hal ini merupakan kekuatan pengaruh sosial dalam mempengaruhi keberanian individu untuk mengutarakan pendapat. Maka di titik ini, kepercayaan terhadap bisnis e-commerce dapat muncul secara relasional-kolektif tanpa melalui analisis kritis dari individu. Hal ini memberikan tambahan terhadap teori-teori kepercayaan terhadap bisnis e-commerce yang selalu digambarkan sebagai kepercayaan individual (cf. McKnight \& Chervany, 2001). Kepercayaan kolektif menegaskan bahwa peranan relasi sosial pada level individual dapat menjadi pembentuk kepercayaan terhadap sebuah vendor e-commerce.

Petikan wawancara di atas juga menunjukkan bagaimana relasi sosial menjadi determinan terealisasinya transaksi ekonomi dalam e-commerce. Subjek penelitian menunjukkan bahwa keputusan untuk membeli salah satunya dilandasi oleh karena adanya rasa kebersamaan. Bahkan dalam konteks risiko, mereka memaknai bahwa setiap keuntungan atau kepuasan serta kerugian terhadap produk atau jasa yang mereka beli adalah hasil dari keputusan bersama. Hal ini tidak dapat dijelaskan dengan logika ekonomi klasik seperti yang dipercayai oleh Adam Smith atau Jeremy Bentham yang cenderung melihat manusia sebagai makhluk yang rasional (Harstad \& Selten, 2013). Dalam konteks ini, subjek penelitian justru memaknai bahwa transaksi ekonomi yang dilakukan secara kolektif adalah perwujudan dari kohesivitas sosial dalam relasi pertemanan. Relasi sosial dalam hal ini memegang peranan penting sebagai asuransi sosial untuk risiko-risiko yang tidak terprediksi. Hal ini menunjukkan bahwa kepercayaan dalam konteks e-commerce dapat muncul sebagai produk pemaknaan individu terhadap relasi sosialnya. 
Eksklusivitas Relasional (Relational Exclusivity). Pada umumnya, individu yang berusia lebih dari 17 tahun dianggap memiliki independensi dalam pengambilan keputusan ekonomi. Hal ini tidak sepenuhnya keliru. Namun demikian, dalam kerangka relasionalisme, individu tetap merupakan bagian dari keluarga yang lebih besar. Konfusius menegaskan bahwa dalam keluarga Asia, relasi antara orangtua dan anak merupakan salah satu bentuk relasi primer yang memiliki otoritas yang absolut sebagaimana dijelaskan dalam Lima Keutamaan Kardinal Konfusius. Anak, meskipun ada dalam fase independen, tetaplah terikat dengan aturan kultural yang mengharuskannya tetap hormat kepada orangtuanya (Hwang, 2012). Temuan mengenai relasi vendor dan keluarga dalam bagian ini menunjukkan bagaimana orangtua tetap memiliki otoritas yang mampu mempengaruhi keputusan ekonomi anaknya. Debbie selama ini membeli barang-barang di sebuah online shop yang merupakan langganan keluarganya. Karena pemilik usaha tersebut memiliki relasi yang karib dengan orangtuanya, Debbie kemudian mengembangkan kepercayaannya kepada vendor tersebut, meskipun tidak selalu bertransaksi dengan harga terbaik. Berikut ini merupakan petikan wawancara mengenai tema tersebut:

"Saya memiliki langganan online shop di mana saya membeli semua di sana. Baju, celana, sepatu, dan lainnya. Pemiliknya adalah teman dekat ayah saya. Orangtua saya memang mendorong saya untuk membeli ke dia supaya mendukung usahanya. Meskipun ada online shop lain yang lebih murah, keluarga kami tetap memutuskan untuk berbelanja di online shopnya dia sebagai bentuk solidaritas. Ketika barang yang kami cari tidak ada, kami baru beralih ke online shop yang lain. Tetapi orangtua saya selalu berpesan agar menomorsatukan usaha milik sahabatnya tersebut". (Debbie, 22 tahun).
Temuan mengenai relasi individu dengan keluarga ini menegaskan bahwa individu bukanlah entitas tunggal, independen, dan terpisah dengan keluarga intinya. Bahkan, logika relasionalisme ini melampaui logika ekonomi yang menerangkan bahwa individu akan mencari keuntungan sebesar-besarnya, dan menghindari kerugian. Temuan di atas menunjukkan pola berbeda: Relasi sosial ditempatkan di atas logika ekonomi, di mana seorang anak tetap harus membeli sebuah barang dari bisnis e-commerce atas perintah orangtuanya. Hal ini menegaskan nilai dari sebuah relasi sosial yang ditempatkan di atas logika transaksional. Secara empiris, tema mengenai eksklusivitas traksaksi sering ditemukan dalam paradigma relasionalisme. Pandangan ini membantah paradigma klasik, yang memandang transaksi ekonomi sebagai even yang bersifat diskrit dengan menafikkan peranan relasi antara penjual dan pembeli (Harstad \& Selten, 2013). Dalam pandangan tersebut, transaksi antara penjual dan pembeli terisolasi secara konteks. Di sisi lain, paradigma relasional membahas mengenai transformasi relasi dari independen menjadi interdependen, dan berorientasi pada relasi jangka panjang dan berorientasi kepada masa depan.

\section{Fase Penegasan Kepercayaan Relasional}

Fase penegasan kepercayaan relasional merupakan fase yang terjadi setelah proses transaksi ekonomi dilakukan oleh subjek. Fase ini dijabarkan menjadi dua tema, yakni konfirmasi relasional mengenai rasa puas dalam bertransaksi dan kesalahan yang tak berarti. Dua tema tersebut merupakan topikropik yang kentara dalam membicarakan tentang peneguhan kepercayaan relasional dalam konteks e-commerce paskatransaksi ekonomi. Dua fase ini juga bersifat tematik dan tidak berbentuk urutan.

\section{Konfirmasi Kepuasan Relasional (Relational Confirmation of Satisfaction).} Fase konfirmasi merupakan fase peneguhan dari kepercayaan yang mulai terbentuk. Pada fase ini, kepercayaan menguat dan semakin kentara karena subjek merasakan 
pengalaman positif dari hasil transaksi yang ia lakukan. Setelah melakukan transaksi pembelian, baik berupa barang atau jasa, subjek akan cenderung untuk melakukan evaluasi relasional. Evaluasi ini merupakan tahapan pelibatan unsur afeksi pada individu terhadap keputusan ekonomi yang telah dilakukan. Maka dalam konteks e-commerce, relasi sosial tidak hanya berperan sebagai referensi dalam melakukan pembelian, tetapi juga unsur yang diperlukan dalam melakukan evaluasi. Evaluasi relasional ini menjadi tahapan yang penting dalam pembentukan kepercayaan relasional. Dalam bagian ini, subjek memberikan penegasan tentang kepuasan-kepuasan yang dirasakan kepada relasi sosial terdekat yang ia miliki. Pada gilirannya, kepercayaan relasional akan terbentuk baik pada subjek yang menjadi aktor utama transaksi, maupun pada relasi sosial sebagai pemberi referensi. Tahapan ini dapat disimak pada petikan wawancara berikut ini:

"Awalnya saya ikut beli karena
menemani Agatha membeli. Tetapi
ternyata memang bagus sih barangnya.
Jadi kurasa kita bisa beli lagi di
(vendor) situ. Aku kepingin nyobain
beli baju lain yang sudah kuincar.
Kemarin kan mau nyobain dulu, lihat
bagus atau nggak. Kalau bagus ya
kenapa nggak? (Membeli lagi,-red)."
(Florence, 22 tahun).

Petikan wawancara tersebut menggambarkan pemaknaan subjek terhadap pembelian yang ia lakukan. Embrio kepercayaan relasional yang telah terbentuk pada fase pra-transaksi ekonomi semakin menguat. Secara keperilakuan, subjek yang mengalami fase ini akan melakukan pembelian berulang, melakukan perilaku berlangganan, atau perilaku-perilaku lain yang mengarah ke pembelian repetitif. Selain itu, perilaku konfirmasi relasional dapat pula berupa berbentuk promosi kepada relasi sosial yang lain, baik secara langsung maupun tidak langsung, melalui media daring (online) maupun luring (offline). Penegasanpenegasan ini menunjukkan peranan penting relasi sosial dalam pembentukan kepercayaan dalam konteks e-commerce.

\section{Permakluman Kesalahan (Negligible}

Mistake). Ada periode dimana subjek merasa tidak puas dengan transaksi ekonomi yang telah dilakukan. Dalam fase ini, subjek cenderung akan membutuhkan peran relasi sosialnya sebagai sarana untuk menciptakan sistem proteksi tentang keraguan yang sedang dialami. Relasi sosial, pada fase ini, kemudian memiliki peranan penting dalam mengurangi keraguan, kesalahan, atau ketidakpuasan yang dialami oleh subjek. Menariknya, atribusi yang tercipta saat fase ini berlangsung cenderung pula mengarah kepada tema-tema relasi. maka secara fenomenologis, relasi sosial dalam konteks e-commerce juga berfungsi sebagai asuransi atau penjamin psikologis. Ilustrasi penjelasan tersebut dapat diperhatikan pada wawancara berikut ini:

"Ya pernah juga salah membeli. Pernah
saya sampai habis hampir delapan ratus
ribu. Tetapi ya tidak apa-apa lah.
Namanya juga untuk teman sendiri.
Masak mau perhitungan sama teman".
(Anne, 20 tahun).
"Tapi terkadang kerugian itu membuat
kami punya cerita lucu bersama-sama.
Itu malah lebih seru waktu diceritakan
lagi". (Elena, 22 tahun)

Berdasarkan kategori konsumen yang telah dipaparkan di atas, konsumen tipe kompulsif cenderung memiliki diskursus yang kental pada topik ini. Pembelian-pembelian pada konsumen tipe impulsif cenderung didasarkan pada rekomendasi orang lain, sehingga kemungkinan terjadinya eror juga menjadi lebih besar. Namun demikian, subjek penelitian, sebagaimana dikatakan oleh Anne dan Elena di atas, menunjukkan bahwa secara prinsip transaksi-transaksi yang ia lakukan tidak hanya berbicara tentang untung dan rugi semata, tetapi juga kebersamaan, kohesivitas, dan tema-tema lain yang mengarah kepada kualitas relasi. Dengan kata lain, kerugian, ketidakpuasan, 
serta afek negatif lain yang dialami pada saat melakukan transaksi pembelian merupakan bagian dari merawat relasi. Bahkan pengalaman kolektif menderita kerugian justru dimaknai sebagai pengalamanpengalaman positif dalam relasi persahabatan. Kerugian atau kesalahan dianggap sebagai sesuatu yang tidak berarti (negligible) dibandingkan dengan relasi persahabatan yang dimiliki.

Temuan-temuan dalam penelitian ini menegaskan bahwa relasionisme memiliki kontribusi dalam membentuk kepercayaan individu terhadap bisnis e-commerce di Indonesia. Relasi sosial tidak hanya berfungsi sebagai penentu kesejahteraan psikologis dalam interaksi sosial, tetapi juga mempengaruhi dinamika interpersonal. Secara holistik, temuan-temuan dalam penelitian ini menunjukkan bahwa kepercayaan relasional dalam e-commerce tidak hanya bersifat diadik resiprokal antara konsumen dan vendor semata, tetapi juga melibatkan kepercayaan dengan relasi sosialnya. Artinya, upaya untuk menciptakan kepercayaan relasional dalam bisnis $e$ commerce tidak dapat hanya dibentuk melalui relasi dua pihak ini, tetapi juga harus memperhitungkan relasi sosial dari konsumen.

Bagian diskusi dalam penelitian ini dibagi menjadi dua bagian besar. Bagian pertama mendiskusikan tentang temuan-temuan yang menunjukkan pemaknaan subjek penelitian mengenai transaksi ekonomi sebagai bagian dari aktivitas perawatan relasi. Pada bagian ini juga dijelaskan tentang perbandingan temuan ini (compare and constrast) dengan perspektif ekonomika keperilakuan. Bagian kedua akan menjelaskan refleksi mengenai adanya pergeseran konsep stranger dalam transaksi $e$-commerce.

Perilaku Ekonomi Relasional (Relational Economics Behavior). Melalui tema-tema pada bagian hasil di atas, dapat terlihat adanya pemaknaan tentang pentingnya merawat relasi sosial sebagai entitas yang penting bagi individu. Melalui sub-bab "eksklusivitas sosial" dan "permakluman kesalahan" di atas, subjek penelitian menunjukkan pemaknaan-pemaknaan fenomenologis yang mengisyaratkan bahwa transaksi ekonomi dalam bisnis e-commerce tidak hanya berkaitan dengan logika untung dan rugi semata, tetapi tentang memelihara hubungan. Maka dalam konteks ini, kepercayaan relasional tidak dapat dijelaskan dengan logika ekonomi klasik, yang pada dasarnya mempercayai bahwa manusia adalah makhluk yang rasional dan berupaya untuk mendapatkan keuntungan yang sebesar-besarnya dengan pengorbanan sekecil-kecilnya. Subjek-subjek penelitian justru menunjukkan bahwa relasi sosial merupakan salah satu alasan yang kuat dalam menyediakan referensi, mengambil keputusan, maupun melakukan evaluasi terhadap keputusan ekonomi yang telah dilakukan. Bahkan ketika hasil evaluasi menunjukkan tren yang negatif pun, atribusi tentang pentingnya relasi sosial justru menjadi pledoi yang kuat dan dimaknai sebagai pengalaman kolektif yang positif dalam relasi persahabatan.

Pada titik tertentu, temuan ini memiliki kemiripan dengan kajian-kajian tentang ekonomika keperilakuan (behavioral economics) yang memandang bahwa manusia dapat bergerak melampaui logika rasionalitas. Namun demikian, temuan pada penelitian ini memiliki perbedaan mendasar dengan konsep ekonomika keperilakuan. Pertama, perilaku ekonomi pada subjek penelitian ini menitikberatkan pada relasi sosial. Artinya, motif keperilakuan yang ditunjukkan oleh konsumen tidak hanya berfokus kepada keuntungan diri sendiri atau dinamika lain yang bersifat egosentris. Subjek dalam penelitian ini justru menunjukkan pola-pola deindividuasi yang menekankan pentingnya menekankan rasa kekitaan (sense of we-ness). Hal inilah yang tidak ditekankan secara khusus pada literatur-literatur ekonomika keperilakuan. Kedua, penelitian ini melibatkan aspek metarelasional. Unsur-unsur kepercayaan dapat 
terbentuk tidak hanya melalui interaksi langsung antara vendor e-comemrce dengan konsumen, tetapi dapat pula muncul dari hasil interaksi relasi sosial konsumen (misal ayah atau teman) dengan vendor $e$ commerce. Hal ini menunjukkan bahwa kepercayaan relasional merupakan sebuah produk interaksi dari relasi yang kompleks. Dua argumen ini menjadi alasan keunikan kepercayaan relasional dalam penelitian ini.

\section{Redefinisi Konsep Orang Asing} (Redefinition of Stranger). Temuan-temuan di atas juga menunjukkan adanya pergeseran terhadap makna orang asing dalam diskursus kepercayaan interpersonal. Berbagai kajian klasik tentang teori kepercayaan interpersonal menunjukkan bahwa individu akan cenderung untuk percaya kepada orang lain yang telah ia kenal, memiliki kebaikan, dan dapat dipercaya (Faturochman, 2011). Secara analog, individu akan cenderung memiliki kewaspadaan tinggi terhadap orang asing. Sangat jarang ditemukan dalam literatur-literatur kepercayaan, bahwa pengambilan keputusan didasarkan oleh referensi yang diberikan oleh orang asing. Hal ini tidak terjadi dalam konteks $e$ commerce. Di dalam transaksi e-commerce, ada dimensi orang asing berupa testimoni. Testimoni-testimoni ini justru berperan penting dalam menentukan apakah subjek akan mengeksekusi preferensinya dalam aksi nyata berupa transaksi pembayaran atau tidak.

Temuan ini menunjukkan bahwa konsep orang asing merupakan konsep yang berbeda dalam konteks kepercayaan relasional pada bisnis e-commerce. Orang asing dalam konteks teori klasik kepercayaan interpersonal lebih berperan sebagai liyan, sedangkan testimoni yang diberikan dalam bisnis e-commerce lebih berperan sebagai ingrup dalam bentuk referensi. Lagi-lagi, referensi dalam konteks e-commerce bisnis tidak lagi semata-mata ditentukan apakah subjek dan para pembeli sebelumnya memiliki relasi yang baik. Kesamaan tujuan sebagai seorang konsumen membuat elemen- elemen teori klasik kepercayaan tidak dapat digunakan untuk menjelaskan fenomenafenomena dalam transaksi e-commerce. Selain itu, hal ini memberikan sinyalemen bahwa anonimitas identitas konsumen tetap dapat menempatkan indidivu sebagai referensi dalam mengambil keputusan ekonomi dalam e-commerce.

\section{SIMPULAN}

Berdasarkan analisis dan interpretasi data di atas, dapat disimpulkan bahwa kepercayaan relasional merupakan entitas yang eksis dalam relasi konsumen dan vendor $e$ commerce di Indonesia. Kepercayaan relasional konsumen tidak semata-mata muncul dari hasil evaluasi terhadap vendor sebagai penerima kepercayaan (trustee), tetapi juga dapat muncul dari hasil interaksi dengan pihak ketiga, baik manusia maupun non-manusia. Pihak ketiga ini lebih jauh tidak hanya berfungsi sebagai sumber referensi, tetapi juga penjamin kepercayaan, serta media untuk membangun pola mitigasi risiko pada konsumen. Selain itu, dapat disimpulkan pula bahwa dalam bisnis $e$ commerce, transaksi ekonomi tidak dapat hanya dipandang dalam kacamata untung dan rugi, tetapi sebagai sarana dalam merawat relasi sosial itu sendiri. Temuan ini semakin menegaskan peranan relasi sosial sebagai penguat kepercayaan interpersonal pada manusia.

Secara aplikatif, hasil penelitian ini dapat dimanfaatkan baik oleh konsumen sebagai referensi yang menggambarkan dinamika transaksi ekonomi dalam dunia e-commerce, serta referensi bisnis bagi para vendor $e$ commerce dalam memahami perilaku konsumen e-commerce. Pada vendor misalnya dapat membuat strategi marketing dalam perspektif relasional daripada individual. Promosi-promosi atau diskon belanja seyogyanya dapat dikemas dengan memanfaatkan relasi sehingga memungkinkan proses pembelian dapat dilakukan secara kolektif. Selain itu, hasil penelitian ini juga menegaskan urgensi untuk 
mengelola testimoni konsumen terhadap barang atau jasa yang ditawarkan, sehingga memungkinkan konsumen memiliki referensi yang memadai sebelum mengambil keputusan untuk membeli.

\section{DAFTAR PUSTAKA}

Agag, G.M. \& El-Masry, A.A. (2016). Why do consumers trust online travel websites? Drivers and outcomes of consumer trust toward online travel website. Journal of Travel Research, $1-23$.

Akter, S., \& Wamba, S. F. (2016). Big data analytics in e-commerce: A systematic review and agenda for future research. Electronic Markets, 26(2), 173-194.

Amaro, S., \& Duarte, P. (2015). An integrative model of consumers: Intentions to purchase travel online. Tourism Management, 46, 64-79.

Amaro, S., \& Duarte, P. (2016). Traveller's intention to purchase travel online: Integrating trust and risk to the theory of planned behaviour. Anatolia, DOI:

10.1080/13032917.2016.1191771.

Beldad, A., de Jong, M., \& Steehouder, M. (2010). How shall I trust the faceless and the intangible?: A literature review on the antecedents of online trust. Computers in Human Behavior, 26(5), 857-868.

Braun, V., \& Clarke, V. (2006). Using thematic analysis in psychology. Qualitative Research in Psychology, 3(2), 77-101.

Chiu, C.M., Wang, E.T.G., Fang, Y.H., \& Huang, H.Y. (2014). Understanding customers' repeat purchase intentions in B2C e-commerce: The roles of utilitarian value, hedonic value, and perceived risk. Information Systems Journal, 24, 85-114.

Faily, S., Power, D., \& Flechais, I. (2016). Gulfs of expectation: Eliciting and verifying differences in trust expectations using personas. Journal of Trust Management, 3(4).

Faturochman. (2011). Dinamika psikologis kepercayaan dan ketidakpercayaan. Research report. Penelitian Fakultas Psikologi UGM.

Garbarino, E., \& Maxwell, S. (2010). Consumen response to norm-breaking pricing events in e-commerce. Journal of Business Research, 63, 1066-1072.

Gregori, N., Daniele, R., \& Altinay, L. (2013). Affiliate marketing in tourism: Determinants of consumer trusts. Journal of Travel Research, 53(2), 196-210.

Guercini, S., \& Runfola, A. (2015). Internationalization through ecommerce. The case of multi brand luxury retailers in the fashion industry. Barbara Stöttinger, Bodo B. Schlegelmilch, Shaoming Zou (eds.) International Marketing in the Fast Changing World (Advances in International Marketing, Volume 26), Emerald Group Publishing Limited, 15-31.

Harstad, R.M., \& Selten, R. (2013). Bounded-rationality models: Tasks to become intellectualy competitive. Journal of Economic Literature, 51(2), 496-511.

Hashima, K. F., \& Fadhilb, N. A., (2017). Engaging with customer using social media platform: A case study of Malaysia hotels. Procedia Computer Science, 124, 4-11. 
Ho, D. Y. F. (1993). Relational orientation in Asian Social Psychology. In U. Kim \& J. W. Berry (Eds.)., Indigenous psychologies: Research and experience in cultural context, 240-259. Newbury Park, CA: Sage.

Ho D. Y. F., Chau A. W. L. (2009) Interpersonal perceptions and metaperceptions of relationship closeness, satisfaction and popularity: A relational and directional analysis. Asian Journal of Social Psychology, 12, 173-184

Hwang, K.K. (2012). Foundations of Chinese Psychology: Confucian Social Relations. New York: Springer.

Hsu F. L. K. (1971). Psychological homeostasis and jen: Conceptual tools for advancing psychological anthropology. American Anthropolologist, 73, 23-44.

Jahanshahi, A. A., Zhang, S. X., \& Brem, A. (2013). E-commerce for SMEs: Empirical insight from three countries. Journal of Small Business and Enterprise Development, 20(4), 849-865.

Jai, T.M., Burns, L.D., \& King, N.J. (2013). The effect of behavioural tracking practices on consumer shopping evaluations and repurchase intention toward trusted online retailers. Computers in Human Behaviour, 29, 901-909.

Kim, M. J., Chung, N., dan Lee, C. K. (2011). The effect of perceived trust on electronic commerce: Shopping online for tourism products and services in South Korea. Tourism Management, 32(2), 256-265.

Lebra, T. S. (1976). Japanese patterns of behavior. Honolulu, HI: The University Press of Hawaii.
Lee, J., Park. D., \& Han. I. (2007). The effect of negative online consumer reviews on product attitude: An information processing view. Electronic Commerce Research and Applications, 7(3), 341-352.

Matt, C., \& Heiss, T. (2016). Product fit uncertainty and its effect on vendor choice: An experimental study. Electronic Markets, 26 (1), 83-93.

McKnight, D. H., \& Chervany, N. L. (2001). What trust means in e-commerce costumer relationships: An interdiciplinary conceptual typology. International Journal of Electronic Commerce, 6, 35-59

Nowell, L., Norris, J.M., White, D.E., \& Moules, N.J. (2017). Thematic analysis: Striving to meet the trustworthiness criteria. International Journal of Qualitative Methods, https://doi.org/10.1177/160940691773 3847

Otim, S., \& Grover, V. (2010). E-commerce: A brand name's curse. Electronic Markets, 20(2), 147-160.

Paswan, A.K., Blankson, C., \& Guzman, F. (2011). Relationalism in marketing channels and marketing Strategy. European Journal of Marketing, 45(3), $311-333$

Redwing Asia (2014). Indonesia's dynamic market internet. Diunduh dari http://redwing- asia.com/marketdata/market-data-internet/.

Sharma, P., Bharadhwaj, S., \& Marshall, R. (2010). Impulse buying and variety seeking: A trait-correlates perspective. Journal of Business Research, 276-283.

Siamagka, N., \& Balabanis, G. (2015). Revisiting consumer ethnocentrism: 
Review, reconceptualization, empirical testing. Journal of International Marketing, 23(3), 66-86.

Singapore Post e-Commerce (2014). Indonesia's e-commerce landscape 2014: Insight into one of Asia Pasific's fastest growing markets. Diunduh dari: http://www.specommerce.com.s3.amaz onaws.com/dl/wp/141215-white-paperindonesia.pdf.

Wang, L., Law, R., Guillet, B. D., Hung, K., \& Fong, D. K. (2015). Impact of hotel website quality on online booking intentions: E-trust as a mediator. International Journal of Hospitality Management, 47, 108-15.
Wilson, R. W. (1974). The moral state: A study of the political socialization of Chinese and American children. New York: The Free Press.

Yulianto, J.E. (2016). Kepercayaan konsumen terhadap pusat perbelanjaan digital di Indonesia. In J.S.A. Utama, J. Abraham, I. Nuralfian, A. Supratiknya. Psikologi dan Teknologi Informasi, 239-257.

Zeugner-Roth, K.P., \& Diamantopoulos, A. (2015). Consumer ethnocentrism, national identity, and consumer cosmopolitanism as driver of consumer behavior: A social identity perspective. Journal of International Marketing, 23(2), 25-54. 